Cadernos de História, Belo Horizonte, v. 22, n. 37, Novembro de 2021

DOI: https://doi.org/10.5752/P.2237-8871.2021v22n37p240-262

\title{
OS ANOS INICIAIS DO FUTEBOL FEMININO EM SANTA CATARINA: SILENCIAMENTOS E RESISTÊNCIAS
}

Felipe Matos

Scientia Consultoria Científica

felipematos@hotmail.com

\section{RESUMO}

Apesar do amplo desenvolvimento quantitativo e qualitativo do campo de estudos da História do Esporte e do Lazer em todo o Brasil, ainda há uma lacuna historiográfica sobre trabalhos que tematizam as décadas iniciais do futebol feminino no estado de Santa Catarina. O presente artigo investiga os espaços ocupados e os papéis desempenhados pelas mulheres no futebol em Santa Catarina ao longo do século XX, prática esportiva que foi por quase quarenta anos proibida por decreto-lei. Tal ação marginalizou a modalidade e retardou o seu desenvolvimento. Constata-se que a prática do futebol feminino no estado esteve em sintonia com o que ocorria nos grandes centros urbanos do país, com o futebol sendo visto como um esporte masculino e masculinizante, reservando papéis periféricos às mulheres. O futebol feminino era considerado algo exótico e esteve permanentemente associado aos discursos de fragilidade, de masculinização dos corpos e às diferenças estabelecidas hierarquicamente entre os gêneros. A prática buscou se desenvolver como atividade educativa e recreativa, foi coibida e estabeleceu estratégias de resistência para continuar sendo praticada até poder se estruturar em suas diversas manifestações profissionais e de lazer.

Palavras-chave: Futebol Feminino; História do Esporte; Relações de Gênero.

Recebido em 3 de setembro de 2020.

Aprovado em 3 de maio de 2021. 
Cadernos de História, Belo Horizonte, v. 22, n. 37, Novembro de 2021

DOI: https://doi.org/10.5752/P.2237-8871.2021v22n37p240-262

\title{
THE EARLY YEARS OF WOMEN'S FOOTBALl in SANTA CATARINA: SILENCES AND RESISTANCES
}

Felipe Matos

Scientia Consultoria Científica

felipematos@hotmail.com

\begin{abstract}
Despite the wide quantitative and qualitative development of the field of studies on the History of Sport and Leisure throughout Brazil, there is still a historiographic gap about works that deal with the early decades of women's football in the state of Santa Catarina. That article investigates the spaces occupied and the roles played by women in soccer in Santa Catarina throughout the 20th Century, a sports practice that was prohibited for about forty years by decree-law, which marginalized the modality and delayed its development. It can be verified that the practice of women's soccer in the state was in sync with what was happening in the large urban centers of the country, with soccer being seen as a symbol of masculinity in the sport, reserving peripheral roles for women. Women's football was considered something exotic and it was permanently associated with the discourses of fragility and masculinization of the bodies and with the differences established hierarchically between the genders. The practice aimed to develop as an educational and recreational activity, it was restrained and established resistance strategies to continue being practiced until it could structure itself in its various professional and leisure manifestations.
\end{abstract}

Keywords: Women's Football; Sport History; Gender Relations. 


\section{INTRODUÇÃo}

Nas últimas décadas, com a consolidação das discussões em torno da História Cultural, abriu-se um leque de possibilidades do fazer historiográfico e do diálogo com outras ciências que permitiu aos historiadores e historiadoras ampliarem sua visão dos temas e dos objetos a serem problematizados, a fim de se ter uma maior compreensão das trajetórias dos homens e mulheres no tempo (BURKE, 2010, p. 8). No esteio dessa renovação dos estudos historiográficos, as pesquisas no campo da História do Esporte e do Lazer no Brasil se expandiram de forma quantitativa e qualitativa, atraindo um número crescente de pesquisadores, fomentando a criação de Núcleos e Grupos de Pesquisa nas universidades. Em consequência disso, incrementou-se a produção bibliográfica sobre o tema, estimulando a realização de eventos acadêmicos diversos, tornando-se um efervescente campo de investigação, com predomínio dos estudos sobre o futebol (FIGOLS, 2018, p.13).

No entanto, em Santa Catarina, apesar de um crescente interesse acadêmico acerca da história do futebol praticado pelos diversos gêneros, os estudos abordando as primeiras décadas da prática do futebol feminino ainda são incipientes - além de ser um recorte temporal pouco explorado na história regional. Justifica-se a necessidade de um número maior de trabalhos que elejam os anos iniciais da prática esportiva e tematizem o desenvolvimento de uma modalidade que por muito tempo esteve à margem do profissionalismo e da legalidade. Afora a relevância historiográfica e social do tema, indo além da mera elaboração de uma narrativa histórica sintética, o objetivo do artigo é demonstrar que a prática do futebol feminino em Santa Catarina (SC) esteve em sintonia com o que ocorria nos grandes centros urbanos do país. O futebol vem sendo visto como um esporte generificado (masculino) e generificante (masculinizante), reservando papéis periféricos às mulheres.

Esta pesquisa se desenvolveu tendo como principais fontes o uso de jornais e periódicos impressos, haja vista o papel fundamental dos jornais na divulgação e popularização do futebol, sendo que os primeiros escritos sobre o futebol foram produzidos por jornalistas e cronistas esportivos (FIGOLS, 2018, p.15). Como será percebido ao longo do texto, por diversas vezes nestes periódicos as atletas foram alvo de metáforas associadas aos papéis esperados para serem desempenhados pelas mulheres, com a linguagem associada a termos que evidenciavam noções de fragilidade, estética, sexualização e feminilidade.

A escrita sobre um esporte permeado por contornos de invisibilidade e de silenciamento requereu a utilização de entrevistas, produzidas tanto pelo autor quanto por terceiros, numa abordagem qualitativa de análise das narrativas. Tais narrativas revelam o cotidiano, as sociabilidades, as representações e processos particulares específicos de cada informante (CHIZZOTTI, 2003).

A perspectiva analítica adotada ao longo do trabalho priorizou estudos que investiram na análise e desconstrução das noções de identidades essenciais de gênero, de inclinação pós-estruturalista, como os trabalhos de Judith Butler e Joan Scott. Sobre as relações entre gênero e esporte, destacamos as contribuições de Silvana Goellner e demais autoras e autores referenciados. 


\section{A PRESENÇA FEMININA NOS ESPORTES NO INÍCIO do SÉCULO XX}

Alinhado com os anseios dos novos tempos do alvorecer republicano, em que teorias higienistas e eugenistas de melhoramento da raça estavam em ascensão, o remo foi a modalidade esportiva que mais se desenvolveu nos primeiros anos do século XX na capital catarinense, se tornando uma prática cultural de grande notoriedade numa cidade-ilha que vivia com intensidade suas sociabilidades marítimas. Neste período, desejava-se a construção de um novo homem para um novo tempo, robusto, com energia e vitalidade, como deveria ser o novo regime, personificado na figura do sportsman, cuja valorização buscava afastar os indivíduos da indolência, dos vícios e das doenças (SARTORI, 2013, p.44).

Os clubes de remo movimentavam a vida social não apenas de seus praticantes, mas de uma camada ampla da população que passou a se identificar com as agremiações formando o corpo das suas torcidas, que ocupavam o cais de Florianópolis nos dias de competição. Mais do que qualquer outro esporte até então, o remo transformava a prática esportiva em um espetáculo organizado em clubes que disputavam campeonatos entre si, criando relações de sociabilidade e de identidade entre os sportsmen e seus aficionados.

Não à toa o substantivo era masculino - não há nos jornais da época a expressão sportswomen. A prática de esportes por mulheres ainda era restrita e, eventualmente, até uma exótica atração de espetáculos circenses. Em 1899, o público florianopolitano pôde presenciar apresentações do Circo Pery, fundado pelo artista Manoel Pery, proprietário de uma afamada companhia luso-brasileira de equitação e ginástica. Nesse espetáculo, se apresentavam ginastas como Francisca e Theresa de Azevedo, além da écuyère brasileira Aristotelina Pery, com seu número de equitação (O ESTADO, 1899, p.1).

A prática feminina era tolerada em atividades que não colocassem em risco os conceitos vigentes de feminilidade, como a elegante patinação. No dia 16 de março de 1915 foi inaugurado na rua Felipe Schmidt, em Florianópolis, o Rink Catharinense, um salão da patinação de propriedade do empresário Júlio Toldo, permitindo também a presença de mulheres:

\footnotetext{
Não se diga que é destinado somente aos jovens; as gentis patrícias também lá encontrarão lugar para a patinação, pois, o operoso proprietário, para esse fim, contratou dois professores, de ambos os sexos, para, em horas previamente marcadas, ensinarem àquelas pessoas que quiserem dedicar-se a esse proveitoso e útil esporte (O DIA, 1915, p.1).
}

Às mulheres foi reservado o horário vespertino, de segunda a sábado. A professora contratada foi Katharina Huber, filha de André Huber, alfaiate e atleta do Florianópolis Futebol Clube. Mas, se as mulheres não podiam frequentar o salão em outros horários, não havia fiscalização ou limites para as atividades masculinas. Segundo um jornal da época, durante o horário destinado às mulheres costumeiramente via-se "(...) diversos marmanjos, que, por obra e graça do proprietário do Rink, são chamados 'professores de patinação', apesar de, com raras exceções, não passarem de simples aprendizes do belo esporte" (O IMPARCIAL, 1916, p.2).

O jornal O Imparcial também denunciou o Rink por supostamente proibir a entrada de negros e praças em seu salão (O IMPARCIAL, 1916, p.1). Tal acusação foi negada por seu proprietário, mas sustentada pelo jornal (O IMPARCIAL, 1916, p.5). Vale registrar os nomes de algumas das frequentadoras do espaço, que estiveram entre as pioneiras da patinação em 
Florianópolis: Noêmia Gevaerd, moradora da rua Felipe Schimidt, onde mantinha uma escola de bordados; Auta Lima, filha de José Pedro de Lima, funcionário dos Telégrafos; as irmãs Brandina e Mary Simmonds (Foto 03), filhas do engenheiro inglês Edward Simmonds; Adelina Vela, então aluna do Colégio Sagrado Coração de Jesus e, posteriormente, membra do Clube Soroptimista de Florianópolis dentre outras (O DIA, 1916, p.3).

O modelo de modernização urbana em voga restringia os espaços e as práticas femininas, pois possuía uma organização familiar e social pautada no patriarcado. Essa desigualdade de gênero era garantida e regulada por lei. O Código Civil brasileiro (CC/1916) regulava funções e tarefas de homens e mulheres, reafirmando valores conservadores: o divórcio era proibido, aos homens cabia exercer a autoridade perante a lei e a desobediência feminina poderia acarretar em consequências judiciais (FREITAS et al, 2019, p.66).

No início do século $\mathrm{XX}$, as mulheres se destacaram no mundo esportivo local como torcedoras, não apenas assumindo uma postura passiva, de mera contemplação dos esportes, mas exercendo importante papel na promoção dos clubes de remo. As mulheres compareciam às competições estimulando os atletas, batizavam os barcos, tornavam-se madrinhas esportivas, cantavam os hinos, vestiam roupas especiais com cores e símbolos de seus clubes, formavam blocos de carnaval das torcedoras, recepcionavam equipes adversárias. Ademais, as mulheres promoviam eventos para celebrar e arrecadar fundos em prol das instituições, inclusive para a construção de suas sedes sociais (REPÚBLICA, 1921, p.4).

Essas torcedoras eram, em grande parte, mulheres jovens, filhas das "famílias tradicionais" relacionadas às elites econômicas e políticas da cidade, sendo frequentemente representadas nos jornais como "gentis senhorinhas da sociedade". Na década de 1910, a grande rivalidade no remo da capital era entre o Clube Náutico Riachuelo e o Clube Náutico Francisco Martinelli, ambos fundados em 1915. As equipes contavam com um grupo fiel de torcedoras organizadas, mas que não remavam, nem se envolviam com a direção administrativa dos clubes.

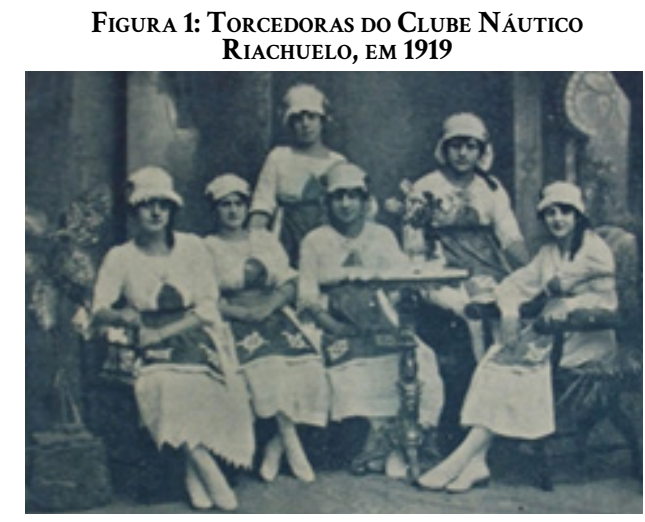

Fonte: reprodução Revista Illustrada, nº4.

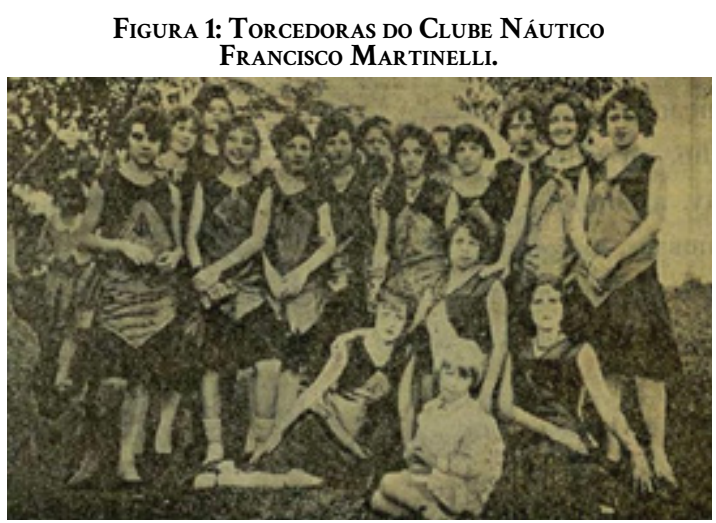

Fonte: reprodução revista Ilha Verde, s/n.

O Clube Náutico Francisco Martinelli contava com um grupo de torcedoras apelidadas de "Martinellinas" ou "Martinellistas", que organizaram quermesses para a promoção do clube e arrecadação de fundos (O DIA, 1918, p. 4). A líder das Martinellinas foi Dora Pederneiras, filha de Nicolau Pederneiras, engenheiro, diretor da Companhia Metropolitana e da Colônia Nova Veneza. Dora residia com sua família na rua Bocaiúva, área nobre da cidade. Ela era membra do Círculo Católico de Florianópolis, sendo reconhecida como uma 
"dama de caridade", participando de diversas campanhas assistenciais a favor da Igreja, da Cruz Vermelha, das vítimas da Guerra do Contestado, entre tantas outras causas enobrecedoras. Segundo o Gazeta do Commercio (1916), também foi membra do Rose Club, um clube de mulheres pertencentes ao "high-life florianopolitano" que organizava soirées dançantes, saraus literários e musicais sob a direção do maestro Álvaro Ramos. Em relação ao Clube Náutico Riachuelo, as torcedoras utilizavam os salões do Clube Doze de Agosto para organizar tardes de chá, domingueiras e concertos em prol do clube (O DIA, 1918, p.3). Além disso, organizaram o Festival das Torcedoras do Riachuelo, com recitação literária e apresentações musicais entre outras atividades (O DIA, 1918, p.1).

Além de Florianópolis, em outras cidades do estado também havia a organização de torcedoras em prol dos seus clubes de preferência. Como exemplo, pode-se citar a cidade de Laguna, onde o Club de Natação e Regatas Lauro Carneiro possuía amplo apoio feminino, com atuação de torcedoras oriundas das camadas mais abastadas da sociedade. Em Itajaí, as torcedoras do Clube Náutico Marcílio Dias, fundado em 1919, arrecadavam fundos para fins beneficentes, como na campanha em auxílio aos flagelados pela seca na região Nordeste brasileira (REPÚBLICA, p.2, 1920).

A prática de outros esportes era mais comum no interior dos colégios. Uma das modalidades permitidas às mulheres nas escolas foi o basquete, embora com adaptações nas regras que o diferenciava da modalidade masculina (GUEDES, 2009, p.22-23). Em 1919, em Florianópolis, os grupos escolares Silveira de Souza e Lauro Müller organizaram um campeonato interescolar de basquete feminino, em celebração a Independência do Brasil (REPÚBLICA, p.1, 1919). A educação física feminina na Primeira República adaptou-se em relação às novidades trazidas pelas disciplinas da Psicologia e Puericultura, preocupadas em manter as mulheres com saúde para a geração de filhos saudáveis. Para as mulheres, os esportes eram permitidos, mas, segundo os preceitos vigentes, apenas aqueles que não pudessem "masculinizá-las" com o aumento de músculos e agressividade, ou que não ameaçassem o controle mental considerado delicado do "sexo frágil". O foco do debate centrava-se nos usos que as mulheres poderiam fazer de seu próprio corpo. Sob a justificativa da proteção da maternidade, transformou-se o corpo feminino numa questão de Estado (FRANZINI, 2005, p. 321).

\section{FOOTBALL, ESPAÇO PARA “GENTIS TORCEDORAS”}

Entre os homens, a partir da década de 1910, o futebol passou a ter maior apelo. Comparado ao remo, o futebol tinha muitas vantagens para se popularizar: poderia ser praticado num campo ou nos vários terrenos baldios, de chuteiras ou descalço, bastava ter uma bola. Mesmo na ausência da pelota, o esporte poderia ser praticado com uma laranja caída, com uma bola feita de meia ou com um jornal amassado. Era um esporte europeu, carregado de marcas civilizatórias, praticado por uma elite e que introduzia uma série de expressões de língua inglesa em sua terminologia. Contudo, o esporte não levou muito tempo para ganhar as ruas, ajudando a tensionar barreiras sociais e raciais entre seus praticantes, quer nas arquibancadas oficiais, quer nos campos de várzea.

Os primeiros clubes de futebol foram surgindo em todo o estado, como o Brazilian 
Foot-Ball Club (Florianópolis - 1911) e o Itajaiense Foot-Ball Club (Itajaí - 1911). Alguns clubes de remo formaram os seus próprios times de futebol, como os clubes náuticos Riachuelo e Martinelli (Florianópolis) e Marcílio Dias (Itajaí). Essa aproximação incentivou parte dos torcedores e torcedoras do remo a migrarem para o futebol. Os times começavam a arregimentar a cada partida uma audiência crescente, fidelizando simpatizantes a partir da popularização das regras do jogo, dos uniformes, chuteiras e bolas.

O futebol conseguiu aliar o lúdico ao pragmático, a seriedade à diversão, a força bruta à habilidade e o esporte à paixão. No entanto, não incluiu as mulheres como praticantes. Tal qual o remo, o futebol era uma prática masculina e masculinizante. Desde sua fundação, em 1904, a Fédération Internationale de Football Association não reconheceu a existência de uma modalidade feminina, o que só aconteceria formalmente na década de 1980. Nesses anos iniciais, coube às mulheres apenas o espaço extracampo. Em 1919, quando Riachuelo e Martinelli deixaram momentaneamente os remos de lado e entraram no gramado para disputar uma partida de futebol amistosa - em benefício do Clube Sportivo Florianópolis - o jornal. O jornal O Estado registrou a presença das "renitentes torcedoras de foot-ball", numa partida em que o sportman Alfredinho (Alfredo Silva), então atleta do Americano Futebol Clube, do Rio de Janeiro, defendeu as cores do Martinelli (O ESTADO, 1919, p.2).

A menção às torcedoras de futebol nos jornais foi se tornando frequente. Em 25 de fevereiro de 1919, na cidade de Tubarão, uma soirée dançante no Clube 7 de Julho reuniu dois grupos de torcedoras do Club Sportivo Barriga Verde e do Hercílio Luz Football Club, fantasiadas com as cores das agremiações para disputar um concurso carnavalesco. As torcedoras continuavam a serem descritas como gentis senhoritas da elite (O DEVER, 1919, p. 3). Em Itajaí, as torcedoras do Marcílio Dias organizavam piqueniques como forma de confraternização (O SPORT, 1919, p.2). A mesma ação foi feita pelas torcedoras do Football Club Rio Branco, do bairro Coqueiros, em Florianópolis (REPÚBLICA, 1921, p.3). Em Tijucas, ficou a cargo das torcedoras do Brazil Football Club a organização de festivais para arrecadar fundos para a agremiação (O PONTO, 1920, p.2). As torcedoras também organizavam festas nos salões locais para recepcionar os sportmen adversários que chegavam à cidade para disputar amistosos (O PONTO, 1920, p.1). Em Lages, as torcedoras do Sport Club Cruzeiro - um dos poucos clubes a contar com uma seção esportiva feminina, com mulheres atletas dedicadas ao tênis e ao basquete - receberam com um chá-dançante a delegação esportiva do Serrano (REPÚBLICA, 1923, p.1).

Essa cortesia entre clubes percebida na análise dos jornais da época era comum especialmente nos amistosos intermunicipais, num período em que o futebol ainda carregava um acentuado ar aristocrático de distinção social, com grande concorrência entre a juventude das elites locais. Os hábitos corteses, o cavalheirismo, a etiqueta e os protocolos de civilidade eram valorizados antes, durante e depois das partidas, com as mulheres exercendo importante papel nesse teatro social, sendo a "gentileza" uma palavra de ordem repetida exaustivamente nos relatos jornalísticos. Quando o clube Brazil, de Tijucas, foi disputar um amistoso contra o Sport Club Brusquense, em Brusque, o jornal O Ponto destacou que a equipe foi recepcionada pelas "gentis torcedoras" do time local (O PONTO, 1920, p.2). Em Biguaçu, a atuação das torcedoras do biguaçuense Football Club foi elogiada pelo jornal República pela "forma gentil” que receberam os jogadores da equipe do Cruzeiro Football Club, do bairro Praia Comprida, 
de São José: "como é hábito da distinta elite daquela encantadora vila” (REPÚBLICA, 1921, p.2).

Quando a torcida feminina não comparecia aos jogos de futebol, a sua ausência também era registrada nos jornais, como ocorreu na ocasião de um amistoso entre os times do Riachuelo e do Ginásio Catarinense, em Florianópolis:

E o que mais notamos no último match desses dois teams, sobretudo, foi a falta das lindas torcedoras, que perderam uma excelente ocasião de vibrarem de entusiasmo pelas cores preferidas de seus corações. Que o encanto, o entusiasmo, o aplauso e a torcida das moças de Florianópolis, não faltem a esse match, são os desejos nossos e dos jogadores (REPÚBLICA, 1920, p.2).

A partir da década de 1920, os ecos das conquistas femininas tornavam a sua presença cada vez mais frequente na vida social das cidades, inclusive no ambiente esportivo, ainda que essa mudança tenha privilegiado inicialmente as mulheres das camadas mais abastadas, em práticas que não ameaçavam a noção de feminilidade em voga.

\section{UM FUTEBOL DE MULHERES: AÇÕES PIONEIRAS}

Independentemente dos discursos hegemônicos e a despeito das convenções sociais, os esportes "seduziam e desafiavam muitas mulheres que, indiferentes às convenções morais e sociais, aderiram à sua prática” (GOELLNER, 2006, p.93). No ano de 1929, a passagem do Circo Irmãos Queirolo por SC ficou marcada por uma de suas atrações: um jogo de futebol de mulheres, em que elas vestiam as camisas de Avaí e Figueirense, os dois clubes de futebol mais populares da capital e as duas maiores rivalidades locais. Estabelecido no Brasil desde 1910, o Circo Irmãos Queirolo chegou a Florianópolis pelo paquete Itaquera, em novembro de 1929, montando seu pavilhão na Praça General Osório, popularmente conhecida como Campo do Manejo. Curiosamente, este foi o mesmo local tradicionalmente apontado como o da realização do primeiro jogo oficial de futebol masculino na cidade, em 14 de agosto de 1910, entre os alunos do Colégio Catarinense e um combinado de paulistas e cariocas.

O circo possuía uma equipe de 79 artistas que se apresentava sob uma lona impermeável, cujos anúncios publicitários nos jornais locais asseguravam que era capaz de comportar até quatro mil pessoas. Há o registro de ao menos uma partida de futebol feminino disputada por "oito gentis senhorinhas" representando Avaí e Figueirense, realizada em 09 de dezembro de 1929 (O ESTADO, 1920, p.6). No Circo Queirolo houve também uma partida entre os times Tamandaré e Adolfo Konder, mas sem a indicação de se tratar de times masculinos ou femininos (REPÚBLICA, 1929, p. 3).

A “espetacularização" do futebol protagonizado por mulheres já fazia parte das atrações do circo dos Irmãos Queirolo desde 1926. Com a eterna necessidade de renovação de repertório e a demanda por novidades, o jogo de futebol feminino era uma carta na manga, pois chamava a atenção da audiência não acostumada a ver mulheres jogando futebol. Investiase nas rivalidades locais, com as artistas utilizando as camisas dos clubes de futebol das cidades em que se apresentavam, além do fato de não necessitar-se de grandes investimentos de tempo para a preparação, resumindo-se a dois jogos de camisa, sem a necessidade de decorar falas ou grandes investimentos no cenário.

Por ser um jogo e um espetáculo, as atrizes jogadoras do circo se apresentavam maquiadas, 
o que contribuía para não colocar em suspeição as noções de feminilidade arraigadas na sociedade. Bonfim (2019) afirma que, embora a atração do futebol feminino apostasse na diversão do público provocada pela anormalidade da situação e reforçasse a estigmatização da imagem das mulheres jogadoras como algo exótico, o futebol circense foi também um investimento num simbolismo subversivo para os padrões da época e colocou em pauta a possibilidade de mulheres exercerem o futebol.

A massificação do futebol masculino no Brasil - que resultou na sua profissionalização, em 1933 - fez com que o esporte se transformasse numa expressão cultural nacional. Com o profissionalismo surgiram ídolos oriundos de camadas populares, como Leônidas da Silva e Domingos da Guia, dois atletas negros que despertaram a identificação com uma parcela da população marginalizada. A máquina de propaganda do Estado Novo colocou o futebol na pauta nacional ao utilizá-lo como ferramenta política. O futebol invadiu os jornais, mas também foi tematizado em livros, peças teatrais e filmes. Na capital catarinense, foi encenada no Cine Theatro Paramount (no interior do Teatro Álvaro de Carvalho), pela Companhia Sper, da atriz Margarida Sper, a peça "Futebol em família”, escrita por Antônio Faro e Silveira Sampaio, numa matinê dedicada "às gentis senhorinhas e exmas. famílias" (REPÚBLICA, 1931, p.8). Era uma comédia familiar em que um rapaz discutia com o seu pai por este não aceitar que ele prosseguisse com a carreira de jogador de futebol. Por fim, o filho torna-se jogador do Fluminense e ganha dinheiro suficiente para custear as despesas de um curso de Medicina, pacificando os dois mundos: a possibilidade de se tornar um profissional do futebol sem estar à margem da sociedade e o apelo ao bacharelismo e ao prestígio de cursos socialmente admirados e hierarquicamente considerados superiores, como a Medicina.

A "febre do futebol" na década de 1930 teve o seu auge durante a Copa do Mundo de 1938, quando a seleção nacional conquistou um inédito terceiro lugar. Alguns meses após o fim da Copa foi criado, em Florianópolis, o time Infantil Feminino Lyra Tennis, fundado em outubro de 1938 por Mimi Bosco Galliani e Nicolina da Silva Velloso Rodrigues, que realizava seus treinos e jogos no Estádio Adolfo Konder, o campo da Liga Santa Catarina de Desportos Terrestres.

O Infantil Feminino nasceu no interior do Lira Tênis Clube, espaço elitista, fundado em 1926 a partir da fusão da Sociedade Lyra e do Tennis Club Florianópolis. Na memória histórica da cidade, o Lira foi por muito tempo associado às elites descendentes de imigrantes, atraindo famílias com sobrenomes como Busch, Malburg, Brüggemann, Voigt, Möellmann, Searles e Sainsbury, em oposição ao Clube Doze de Agosto, que a partir do Estado Novo agregou nomes simpatizantes da oligarquia Ramos. A sede do Lira que em 1938 já estava localizada num amplo lote entre as ruas Tenente Silveira e Felipe Schmidt não possuía campo de futebol, justificando, assim, a escolha do estádio Adolfo Konder, principal campo da cidade, para a prática do futebol infantil feminino.

Maria Paulina "Mimi” Bosco Galliani nasceu em 17 de abril de 1889 e faleceu em 12 de abril de 1990, em Florianópolis, tendo se casado com o comerciante José Galliani. Ao se pesquisar nos jornais do período, constata-se que Mimi comandou, em 1939, trinta e nove bandeirantes do núcleo Anita Garibaldi (O ESTADO, 1939, p.6). Não foi possível averiguar se esse envolvimento com as bandeirantes já havia iniciado antes da prática do futebol, mas, o bandeirantismo - ramo feminino do escotismo e mais um espaço em que 
as mulheres exerceram novos papéis na comunidade - seguia valores morais cristãos e tinha uma orientação educativa. Isso pode ter contribuído para que a prática do futebol por meninas pudesse ocorrer, numa época em que havia certo consenso em torno da necessidade de se realizar trabalhos educativos através de novas técnicas de ensino, envolvendo moral e civismo, preceitos de higiene e disciplina do corpo. Foi em 1938 que o Interventor Nereu Ramos criou o primeiro curso de formação de professores para a Educação Física de SC, um curso com duração de seis meses, realizado em Florianópolis, do qual os professores saíam habilitados para lecionar a disciplina nas escolas de todo o estado (BOMBASSARO \& VAZ, 2000, p.114-115).

A outra fundadora do time feminino foi Nicolina Velloso (Foto 04), nascida em Ouro Preto, Minas Gerais, filha de Manoel Pedro da Silva e de Virgínia da Silva. Nicolina morava no Rio de Janeiro e era órfã de pai e mãe quando se casou, em 1924, com Agapito Velloso Rodrigues, um carioca do bairro Madureira. No registro de casamento consta sua data de nascimento como sendo 10 de outubro de 1903. No entanto, segundo declaração do neto de Nicolina (VELLOSO FILHO, 2020), essa data provavelmente não é a verdadeira, pois teriam falsificado os seus documentos para que ela pudesse se casar ainda menor de idade. Os jornais de Florianópolis registram a sua data de aniversário como sendo 10 de dezembro $(\mathrm{O}$ ESTADO, 1935, p.6).

Após o casamento, Nicolina e Agapito se mudaram para Florianópolis. Ela era dona de casa e deu à luz a quatro filhos. Ele trabalhou inicialmente como oficial da Força Pública, posteriormente como funcionário da Delegacia Fiscal e, por fim, como topógrafo do Serviço de Patrimônio da União. Apaixonado por futebol, o marido de Nicolina envolveu-se com os clubes locais atuando como técnico e dirigente, colaborou por décadas com a Federação Catarinense de Futebol (antiga Liga Santa Catarina de Desportos Terrestres) como membro do conselho fiscal, do quadro de árbitros e como tesoureiro. De acordo com Velloso Filho (2020), em 1938, ano em que Nicolina fundou a equipe infantil feminina, Agapito havia sido contratado pela Liga Florianopolitana de Futebol para ser o zelador do estádio Adolfo Konder, residindo em uma casa ao lado do campo com sua família. Ou seja, para ministrar as aulas de futebol para as meninas, Nicolina só precisava caminhar alguns metros em seu quintal.

O Infantil Feminino Lyra Tennis possivelmente teve vida efêmera, a julgar pela exiguidade de informações e de menções encontradas nos jornais da época. No próprio Lira Tênis Clube, atualmente, não se encontra dados sobre a criação do time. A prática do futebol feminino, entretanto, continuou a se expandir no país. No Rio de Janeiro, surgiram tantas equipes femininas que a Federação Atlética Suburbana organizou o seu primeiro campeonato em 1940, com Leônidas da Silva sendo convidado para ser o técnico da equipe do Império. No time do Casino Realengo, a centromédio Targina começava a ganhar fama como a melhor jogadora do futebol brasileiro. A goleira Filhinha, do Esporte Clube Brasileiro, era apelidada de "o Batatais dos campos femininos", em alusão ao afamado goleiro do Fluminense (O ESTADO, 1940, p.2). 
Figura 3: As patinadoras Mary e Brandina SIMMONDS, EM 1916.

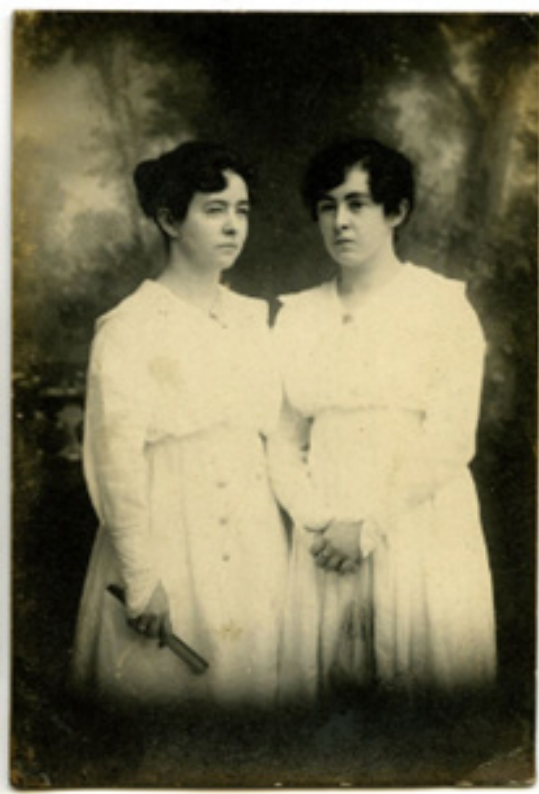

Fonte: Acervo do autor.
Figura 4: Nicolina da Silva Velloso RODRIGUES, EM 1938.

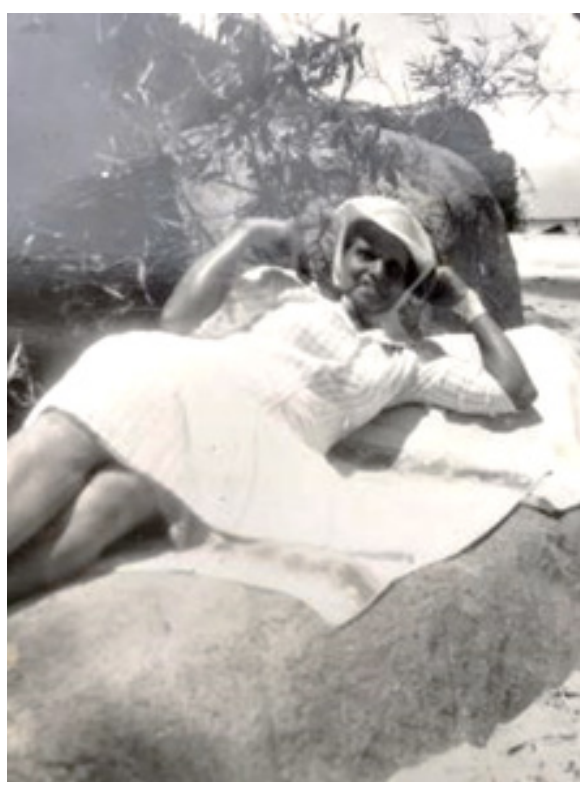

Fonte: acervo de Nilo Velloso Filho.

À medida que se popularizava, aumentavam as críticas ao futebol feminino em discussões que foram reproduzidas nas páginas dos jornais catarinenses. O jornal O Estado, dirigido pelo jornalista Altino Flores, prócere do Figueirense Futebol Clube, saiu em defesa do futebol feminino, admoestando as críticas recebidas pelo esporte, embora apelasse para que se executasse um futebol sem "excessos":

(...) Não admira que se insurjam contra o futebol feminino, se até há ainda quem condene o futebol dos homens. Vozes que não devem encontrar eco, sobretudo, quando as próprias autoridades do país se empenham em revigorar, por meio da educação física, a mocidade brasileira de ambos os sexos (...). Deixem-nas jogar futebol, se elas quiserem e puderem. Basta velar pela pureza desse futebol evitando excessos (O ESTADO, 1940, p.3).

O jornal A Notícia, de Joinville, reproduziu um texto de Salathiel Campos, jornalista negro e militante, membro fundador da Frente Negra Brasileira (SOUZA, 2018), defendendo a prática do futebol feminino e expondo as relações de poder e masculinidade presentes na discussão:

É o ciúme que desperta a veleidade masculina. Certo de que a exibição de força é um espetáculo que embasbaca e a sua superioridade está mais ou menos patente (...), o homem vê fugir-lhe essa supremacia diante da capacidade feminina e sente-se diminuído em seu valor, se reconhecer que era apenas aparente a força demonstrada na prática do futebol (A NOTÍCIA, 1940, p.7).

Como destacou Salathiel Campos, o futebol praticado por mulheres desafiou a esperada subordinação feminina, arraigada em fortes padrões de feminilidade que o futebol parecia subverter. Com as mulheres ocupando espaços e desempenhando papéis antes exclusivos aos homens, a "sua liberdade começava a fazer afronta aos costumes da época" (GOELLNER \& KESSLER, 2018, p. 34). Esse avanço feminino sobre o futebol provocou uma reação que foi uma demonstração de força e de poder masculino: a publicação do Decreto-Lei 3.199, de 14 de abril de 1941, redigido sob forte influência dos discursos higienistas e religiosos, 
que buscavam legitimar os valores sociais conservadores. $\mathrm{O}$ art. 54 do decreto deliberava a proibição da prática de desportos considerados incompatíveis com as condições de "natureza" feminina (BRASIL, 1941).

Os argumentos levantados para justificar a proibição apontavam para uma defesa da proteção à fertilidade feminina, que poderia ser ameaçada pela violência esportiva. As mulheres teriam ossos mais frágeis, menor massa muscular, um coração menor, pulmões menos apropriados, um sistema nervoso que poderia abalar-se com mais facilidade, uma anatomia menos propensa aos esforços físicos, menos glóbulos vermelhos e inúmeros outros motivos postos em discussão na busca por uma cientificidade legitimadora da repressão. Na realidade, buscava-se inibir a subversão de se ter mulheres adentrando em espaços tipicamente masculinos (SOUZA et al., 2019, p.284).

Em SC, esportes como basquete, vôlei, bolão, tênis e atletismo continuaram sendo praticados por mulheres por não representarem uma ameaça aos códigos de feminilidade vigentes ou por terem sido adaptados em busca de uma readequação às possibilidades fisiológicas e sociais a que o corpo feminino estava autorizado. $\mathrm{O}$ decreto-lei, no entanto, desarticulou em todo o país a crescente organização feminina em equipes e campeonatos de futebol que começavam a ganhar corpo.

\section{A RESISTÊNCIA EM CAMPO: FUTEBOL EM TEMPOS DE PROIBIÇÃO}

Mesmo com as dificuldades e limitações impostas pelo Decreto-Lei 3.199, as mulheres continuaram a entrar em campo. O ano de 1951 tornou-se outro marco para o futebol de mulheres em Santa Catarina, pois foi quando houve, em 02 de junho de 1951, a realização de uma partida entre dois quadros adultos no estádio da Federação Catarinense de Desportos, em Florianópolis, fato que foi destacado pela imprensa da época como algo até então inédito no Estado (O ESTADO, p.4, 06 jun. 1951).

Tratou-se de uma partida amistosa entre as equipes Tiradentes (Foto 05) e Amazonas, ambas do Rio Grande do Sul, que excursionavam pelo sul do país realizando jogos exibições. As duas equipes surgiram em 1950, em Porto Alegre, organizadas pelo departamento esportivo do Grêmio Esportivo Renner, que mantinha uma equipe de futebol masculina participando dos campeonatos oficiais sul-rio-grandenses com relativo sucesso. Os jogos em Porto Alegre atraíram interesse do público, o que fez com que fossem organizadas excursões das equipes femininas pelo interior do estado em jogos exibições. Em 22 de outubro de 1950, as equipes duelaram em Caxias do Sul, no estádio da Quinta dos Pinheiros. O Amazonas venceu o Tiradentes por dois a zero, numa partida que arrecadou Cr\$26.400,00 nas bilheterias, o que foi considerado pela imprensa local "uma soma apreciável" (O MOVIMENTO, 1950, p.5). Antes de desembarcarem em Florianópolis, Amazonas e Tiradentes haviam jogado em Curitiba, onde a partida teria arrecadado mais de cem mil cruzeiros (LUME, 1951, p.5).

Em Florianópolis, a exibição dos quadros femininos foi contratada pelo Paula Ramos Esporte Clube, que mantinha uma equipe masculina de futebol, além de outras atividades esportivas em sua sede social. A cobertura do jornal $O$ Estado deixou transparecer que o evento foi um sucesso de público, atraindo grande audiência:

(...) a peleja, pelo seu ineditismo em nosso Estado, tomou conta das atenções do público, 
fazendo com que o estádio da rua Bocaiúva [Estádio Adolfo Konder] ficasse superlotado e a renda atingisse a importância de 60 mil cruzeiros, segundo os nossos cálculos, representando recorde de bilheteria (O ESTADO, 1951, p.4).

Apesar da expectativa causada, a partida não transcorreu conforme planejado. Marcada para ter início às $15 \mathrm{~h} 30 \mathrm{~min}$, o jogo foi iniciado às $17 \mathrm{~h} 30 \mathrm{~min}$, ao escurecer, devido ao atraso do avião que conduzia as duas equipes. Como o estádio não possuía iluminação para jogos noturnos, foram jogados apenas quinze minutos, tendo o restante do jogo sido realizado na manhã do dia seguinte, com entrada franca. Na crônica esportiva, as mulheres atletas foram apresentadas como "Evas" - em referência à primeira mulher criada por Deus a partir das costelas do primeiro homem, segundo a tradição judaico-cristã. Ademais, as jogadoras foram descritas com pouca técnica e potência nos chutes, mas com destaque para características femininas como "vivacidade, graça, ritmo"; a atleta Virgínia, média do Tiradentes, recebeu destaque por fazer "algumas habilidades com a pelota mais parecendo do sexo forte do que do fraco” (O ESTADO, 1951, p.4).

Após o término da partida na manhã de domingo, dia 03 de junho de 1951, as equipes partiram imediatamente para Blumenau, onde, no mesmo dia, disputaram outro jogo, no campo do Grêmio Esportivo Olímpico. As jogadoras foram aguardadas com grande expectativa e atraíram interessados de muitas localidades vizinhas: "o espetáculo de logo mais constitui uma novidade para os blumenauenses. Nunca assistimos aqui, e constitui na verdade coisa muito rara, a exibição de moças praticando futebol” (LUME, 1951, p.5). Desta vez, o Amazonas venceu por 4 a 2. O jornal Lume destaca, ainda que "para se ter ideia da multidão presente, basta apontar a arrecadação financeira verificada: Cr\$42.000,00” (LUME, 1951, p.5).

Verifica-se que o Decreto-Lei 3.199 não proibiu explicitamente a prática do futebol feminino, embora o enquadramento implícito do futebol como desporto considerado incompatível com a "natureza feminina" revelasse que já havia na sociedade concepções generalizadas de que ele não era uma prática feminina (BRASIL, 1941). A redação do art. 54 do Decreto-Lei dizia apenas que caberia ao Conselho Nacional de Desportos baixar instruções às entidades desportivas do país sobre os esportes que não deveriam ser praticados por mulheres. Como o Conselho demorou para realizar tal tarefa oficialmente, acabou proporcionando uma brecha jurídica para que jogos femininos de futebol continuassem não apenas ocorrendo - em alguns casos até com mandados de segurança obtidos na Justiça - como adquirindo alguma popularidade em modalidades como o futebol de salão feminino, que ganhou adeptas no Brasil a partir da década de 1950 (SILVA, 2015, p.12).

Em 1959, o Conselho Nacional de Desportos, através da atuação de seu vice-presidente, Manoel Maria de Paula Ramos e de seu assessor jurídico, Samuel Sabat, aumentou a repressão ao esporte, reafirmando explicitamente a proibição do futebol feminino, inclusive o de salão, através do parecer interno n¹63-57 (O ESTADO, 1959, p.6). O assunto foi tema de coluna do jornalista Paulo da Costa Ramos, no jornal O Estado, de Florianópolis, que escreveu uma defesa do futebol feminino, ainda que em tom jocoso, em que se nota os anseios pela estilização dos corpos, na expectativa de se ver atletas a performar em campo a feminilidade para deleite do público masculino: 


\begin{abstract}
Mas, será que o senhor é tão ingênuo ao ponto de ainda não ter descoberto que o que menos se faz numa partida de futebol feminino é jogar o dito? (...) O único perigo que correm as moças, durante os 90 minutos regulamentares, é o de serem atacadas pela assistência, entusiasmada com os seus driblings, perdão, eu queria dizer suas pernas. (...) Porque, sr. Paula Ramos, o povo está ficando cansado das pernas tortas de Garrincha, e de vez em quando uma Vera Regina na ponta direita para variar, não faria mal a ninguém... (O Estado, 1959, p.3).
\end{abstract}

Na década de 1960, mulheres desportistas ganharam popularidade nacional, como a tenista Maria Esther Bueno. Contudo, o futebol feminino permaneceu marginal, com outros esportes ganhando espaços no lazer e como possibilidade competitiva. Embora os jogos continuassem a ser realizados, a proibição condenou a prática ao ostracismo, impossibilitou o desenvolvimento físico e técnico das atletas, barrando totalmente qualquer possibilidade de surgimento de um processo de profissionalização das jogadoras, da organização de clubes ou entidades femininas.

A coibição também robusteceu a representação do futebol como um microcosmo masculino, que não comportava a participação de mulheres em espaços de poder, dentro e fora de campo, nos gramados ou no comando técnico de equipes, na direção dos clubes ou na arbitragem, tendo consequências inclusive no afastamento da presença feminina nas arquibancadas. A insistência para que formas de masculinidades e feminilidades fossem rigidamente estabelecidas como opostas afirmou a existência de normas para os gêneros e para as performances de gênero. $\mathrm{O}$ que se apreende é um modelo discursivo hegemônico da inteligibilidade do gênero definido oposicional e hierarquicamente (BUTLER, 2003, p.16). A partir da fixação da supremacia masculina, legitimaram-se regimes normativos que legislaram sobre as vidas das mulheres, categorizando-as socialmente e estabelecendo o que deveria ser permitido ou esperado delas.

\title{
UM NOVO COMEÇO: O PERÍODO PÓS-PROIBIÇÃO
}

A partir da revolução cultural da década de 1960, houve uma maior emancipação sexual que colocou a discussão da liberdade feminina na agenda pública de debates, embora tenha igualmente ocorrido uma maior sexualização da imagem da mulher. Foi um período em que as mulheres conquistaram uma fatia do mercado de trabalho e os movimentos feministas avançaram. No futebol, houve a institucionalização de uma Federação Internacional do Futebol Europeu Feminino, que apoiou a realização do primeiro Campeonato de Futebol Feminino de seleções, realizado na Itália, em 1970, sem a participação do Brasil.

Esses avanços contribuíram para recolocar o futebol feminino em pauta na imprensa brasileira. Há registros de jogos femininos sendo realizados antes mesmo do fim oficial da proibição, no interior de escolas, em atividades festivas oficiais do calendário de eventos municipais, em eventos beneficentes. Em 1967, durante as celebrações do cinquentenário do município de Joaçaba, foram organizadas duas equipes compostas de torcedoras do Cruzeiro Atlético Clube (Foto 06) e do Grêmio Esportivo Comercial (Foto 07) para a disputa de um clássico beneficente realizado no Estádio Oscar Rodrigues da Nova.

$\mathrm{Na}$ capital do estado, o futebol de mulheres ressurgiu em 1971, no interior das escolas, reunindo equipes de instituições como o Colégio de Aplicação da UFSC e a equipe do 
Colégio Coração de Jesus, organizada pelo professor Marc Aurélio Krieger, participando de competições pioneiras, como o campeonato organizado pelo Lagoa Iate Clube, em setembro de 1971 (O ESTADO, 12/9/1971). Alunas do Instituto Estadual de Educação organizaram partidas para arrecadar fundos para o Movimento Pró Estudante Necessitado (O ESTADO, 25/6/1971). Neste mesmo ano, na cidade de Joinville, as normalistas do Colégio Celso Ramos organizaram uma partida de futebol para levantar verbas para o pagamento da sua formatura no estádio do Caxias Futebol Clube (O ESTADO, 25/5/1971).

No município de Canoinhas, o futebol feminino entrou na agenda de comemorações da celebração do Dia da Independência, com as estudantes do Colégio Estadual Santa Cruz Cadernos de História, v. 22, n. 37, p. 237-258, 2021251 Felipe Matos disputando uma partida contra as colegas do Colégio Comercial, no Estádio Benedito Therézio de Carvalho Júnior. Isso ocorreu como preliminar de um jogo entre a seleção masculina municipal e o Caxias Futebol Clube, de Joinville (CORREIO do Norte, 1975, p.6). O mesmo ocorreu no ano seguinte, quando as estudantes atuaram na preliminar de um jogo entre a seleção masculina do município e o então recém fundado Joinville Esporte Clube, novamente durante a celebração do Dia da Pátria (CORREIO do Norte, 1976). Ainda em 1976, no município de Palmitos, equipes femininas (Foto 08) faziam a preliminar dos jogos entre a equipe local masculina do Esporte Clube Recreativo Palmitos e algum adversário visitante (KLÜSER, 2019, p.22).

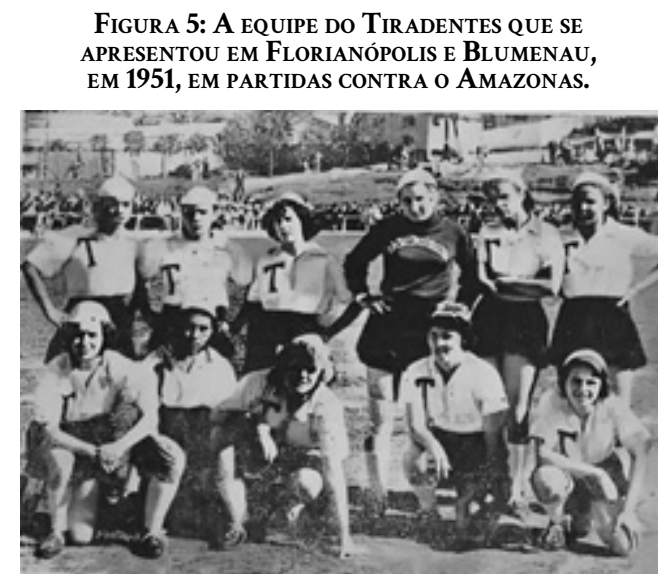

Fonte: Acervo de Adalberto Jorge Klüser.

Figura 7: EQUiPE FEMININA Do GrÊMIO ESPORTIVO COMERCIAL, DE JoAÇABA, EM 1967.

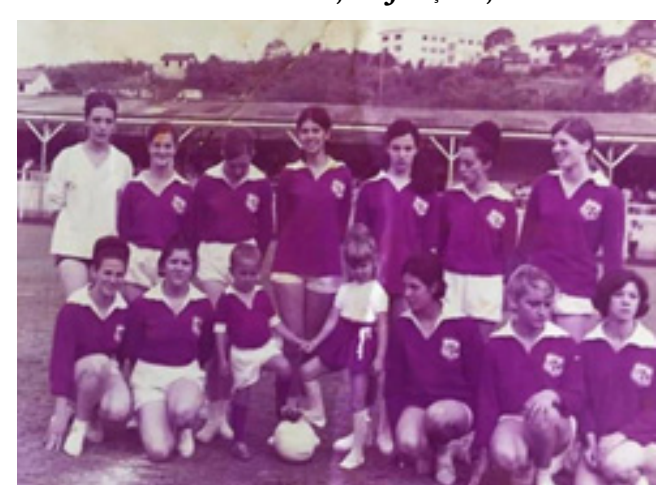

Fonte: Acervo de Antônio Carlos Pereira.

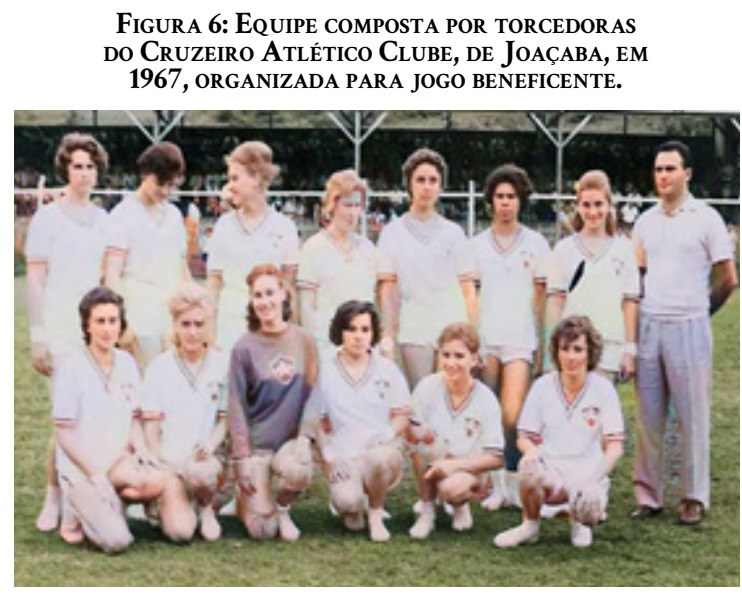

Fonte: Acervo de Antônio Carlos Pereira.

Figura 8: FUTEBol FEMININO NO MUNICíPIO DE Palmitos, em 1976.

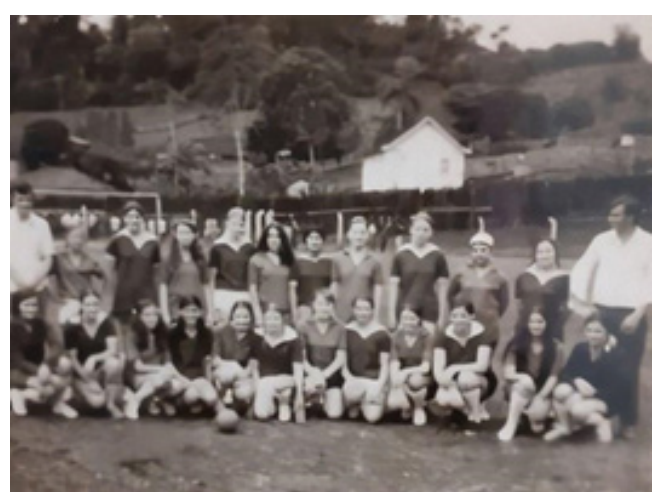

Fonte: Acervo de Adalberto Jorge Klüser. 
A proibição ao futebol feminino só foi extinta oficialmente em 1979 por interferência do Diretor da Confederação Brasileira de Judô, Joaquim Mammed. Ele inscreveu quatro mulheres trocando seus nomes por masculinos na comunicação feita ao Conselho Nacional de Desportos, garantindo que elas participassem do Campeonato Sul-Americano de judô de 1979. Conforme Silva (2003), quando Mammed retornou ao Brasil, teve que prestar contas ao Conselho sobre o seu ato, mas o impacto causado pelas medalhas conquistadas pelas mulheres na competição fez com que, no mesmo ano, a entidade decidisse permitir a prática de esportes conforme condições estabelecidas pelas entidades internacionais de cada desporto.

A liberação não significou qualquer tipo de incentivo por parte de políticas públicas para o engajamento feminino nos esportes naquele momento, mas foi uma grande conquista, por retirar os entraves jurídicos para a sua prática. De acordo com Silva (2003), no caso do futebol, a primeira legislação regulamentadora surgiu apenas em 1983, a partir do interesse do Governo Federal em se inserir no cenário das competições internacionais. Até então, nesse período entre a liberação e a regulamentação, o futebol feminino só pôde ser praticado como forma de lazer, sem a possibilidade de profissionalização. Em SC, na década de 1980, surgiram as primeiras equipes de futebol feminino por todo o estado (Quadro I).

Os desafios, no entanto, continuavam grandes. A desigualdade de gênero estava estruturada dentro das próprias instituições superiores de ensino. No curso de Educação Física da Universidade Federal de Santa Catarina ingressavam anualmente oitenta novos alunos, com metade das vagas reservada para as mulheres que, no decorrer do curso, poderiam exercer as mesmas atividades que os homens, exceto o futebol: a modalidade era exclusiva para os homens, apesar da crescente divulgação do futebol feminino (JORNAL DO BETO, 1983, p.7).

QUAdRo 1: LEVANTAMENTo PRELIMINAR DE EQUIPES FEMININAS DE FUTEbol EM SANTA CATARINA, COM A REGIÃo E UM ANO DE REFERÊNCIA DE SUAS ATIVIDADES.

\begin{tabular}{|c|l|l|}
\hline Ano & \multicolumn{1}{|c|}{ Municípios } & \multicolumn{1}{c|}{ Equipes } \\
\hline 1938 & Florianópolis & Infantil Feminino Lira Tênis Clube \\
\hline 1958 & Criciúma & Comerciário Esporte Clube \\
\hline 1958 & Criciúma & Atlético Operário Futebol Clube \\
\hline 1967 & Joaçaba & Grêmio Esportivo Comercial \\
\hline 1967 & Joaçaba & Cruzeiro Atlético Clube \\
\hline 1971 & Joinville & Colégio Celso Ramos \\
\hline 1971 & Florianópolis & Instituto Estadual de Educação \\
\hline 1971 & Florianópolis & Colégio Aplicação \\
\hline 1971 & Florianópolis & Colégio Coração de Jesus \\
\hline 1975 & Canoinhas & Colégio Estadual Santa Cruz \\
\hline 1975 & Canoinhas & Colégio Comercial \\
\hline 1976 & Palmitos & Esporte Clube Recreativo Palmitos \\
\hline 1980 & Jaraguá do Sul & Esporte Clube Figueirense \\
\hline 1980 & Jaraguá do Sul & Gávea \\
\hline 1983 & Florianópolis & Flachopp \\
\hline 1983 & Florianópolis & Ação Esportiva \\
\hline 1983 & Criciúma & Criciúma Esporte Clube \\
\hline
\end{tabular}




\begin{tabular}{|c|c|c|}
\hline 1983 & Florianópolis & Pioneiro \\
\hline 1983 & Florianópolis & Caramuru \\
\hline 1983 & São José & América Recreativo Futebol Clube \\
\hline 1983 & Palhoça & Catarinense \\
\hline 1983 & Florianópolis & Águia Esporte Clube \\
\hline 1983 & Jaraguá do Sul & Panteras \\
\hline 1983 & Jaraguá do Sul & Associação Atlética Kohlbach \\
\hline 1983 & Jaraguá do Sul & Arweg \\
\hline 1983 & Jaraguá do Sul & Cyrus \\
\hline 1984 & Jaraguá do Sul & Colégio Divina Providência \\
\hline 1987 & Jaraguá do Sul & Esquadrão Classe A \\
\hline 1989 & São José & Scorpions \\
\hline 1992 & Imbituba & Irmãs de Sangue \\
\hline 1992 & Garopaba & Mangueira \\
\hline 1993 & Estadual & Seleção Catarinense \\
\hline 1993 & Chapecó & Chapecoense \\
\hline 1993 & Florianópolis & UFSC \\
\hline 1993 & Palhoça & Paysandu \\
\hline 1993 & São José & Caçula \\
\hline 1993 & Florianópolis & Canto do Rio \\
\hline 1993 & Grande Florianópolis & Internacional \\
\hline 1993 & Grande Florianópolis & Bate-Bola \\
\hline 1993 & Biguaçu & Limeira \\
\hline 1993 & Grande Florianópolis & Aventureiras \\
\hline 1993 & Criciúma & Sete de Setembro \\
\hline 1993 & Governador Celso Ramos & Amazonas \\
\hline 1993 & São José & ERA Phenix \\
\hline 1993 & Jaraguá do Sul & Grêmio Esportivo Juventus \\
\hline 1993 & Schroeder & Seleção Municipal \\
\hline 1995 & Jaraguá do Sul & Colégio São Luiz \\
\hline 1996 & Florianópolis & Estrela do Mar \\
\hline 1996 & Lages & Tortelli \\
\hline 1996 & Lages & Penharol \\
\hline 1996 & Jaraguá do Sul & Esporte Clube Serenata \\
\hline 1997 & Região Oeste & 32 times \\
\hline 1998 & Florianópolis & Avaí Futebol Clube \\
\hline 1998 & São José & Canarinho \\
\hline 1998 & São Francisco do Sul & Seleção Municipal \\
\hline 1999 & Florianópolis & Tornado \\
\hline
\end{tabular}

$\mathrm{Na}$ Universidade do Estado de Santa Catarina - UDESC, a situação era diferente, já que foram as alunas do curso da sua Escola Superior de Educação Física, em Florianópolis, que serviram de base para um dos principais times de futebol feminino deste período pósregulamentação, a equipe do Ação Esportiva (Foto 09). O time foi fundado em 1983 pela 
empresa Central de Promoções e Propaganda Ltda., que editava a revista Ação Esportiva, sobre esportes em Santa Catarina e a revista Encontro, um guia turístico e informativo sobre o estado. A intenção do grupo empresarial era montar uma equipe de futebol feminino e promover jogos em estados como o Rio Grande do Sul e em países como Uruguai e Argentina, locais de origem de um grande fluxo de turistas com destino a Santa Catarina. Conforme se encontra na Ação Esportiva (1983), durante os jogos, seriam distribuídos exemplares das duas revistas, além de outras formas de divulgação do potencial turístico do estado. Suas partidas também foram preliminares de jogos masculinos como o amistoso entre a Seleção de Brasília e um combinado Avaí/Figueirense, em prol das vítimas das enchentes em Santa Catarina, no Estádio Orlando Scarpelli.

Tanto o presidente da Ação Esportiva, Amadeu B. Gonçalves, quanto o seu diretor de futebol, o jornalista Ignácio Girardi, pouco entendiam sobre futebol feminino e sequer conheciam jogadoras que pudessem defender o time que pretendiam criar. Foi através da professora de Educação Física Gladys da Rosa que o elenco foi montado. Ela arregimentou alunas da Escola Superior de Educação Física da UDESC sob o comando do técnico e preparador físico Jairo José Assumpção, formando uma forte equipe, que em seus sete primeiros jogos obteve seis vitórias e um empate, com 57 gols marcados e 3 sofridos. Esses números superlativos demonstram tanto a qualidade do elenco da Ação Esportiva quanto a diferença de patamar entre os times, escancarando o desnível técnico que o mínimo de investimento numa equipe com uma comissão técnica restrita a um técnico e a uma massagista era capaz de produzir. De acordo com a Ação Esportiva (1983), grande parte do elenco já atuava junto nos campeonatos estudantis interfases da UDESC.

$\mathrm{Na}$ década de 1980, também nasceu um dos mais longevos times de futebol feminino do estado, a Associação Esportiva Scorpions, atualmente filiada à Liga Josefense de Futebol, à Federação Catarinense de Futebol e à Confederação Brasileia de Futebol. A Associação foi fundada em 01 de outubro de 1989 no bairro Flor de Nápolis, em São José, com equipes de futebol de campo, Futebol 7, beach soccer e futsal. Sem um local adequado para realizar os seus treinamentos, elas utilizavam as quadras públicas de areia da Avenida Beira Mar, de São José, o que não as impediu de se tornarem uma equipe extremamente competitiva, conquistando diversos títulos em torneios e competições das ligas de futebol amador da região da Grande Florianópolis, torneios estaduais e nacional, estreando em 2007 na 1a Copa Brasil de Futebol Feminino e na 1 ${ }^{\mathrm{a}}$ Liga Nacional de Futebol de Campo, disputada no Rio de Janeiro, que rendeu a uma de suas atletas uma convocação para a seleção brasileira sub-17 (ASSOCIAÇÃO..., 2020).

$\mathrm{Na}$ década de 1990, houve um grande impacto no esporte com a realização da primeira Copa do Mundo organizada pela FIFA (1991) e a inclusão da categoria nas Olimpíadas de Atlanta (1996), aumentando a exposição da parte mais visível do futebol feminino nacional, a Seleção Brasileira. Embora com todas as dificuldades e uma crônica falta de investimentos quando comparada à milionária seleção masculina nacional, esses grandes eventos proporcionaram alguma estruturação do futebol nacional e a busca por atletas em diversas regiões do país, com a atuação de olheiros.

Esse crescimento culminou com a formação da Seleção Catarinense de futebol, em junho de 1993. Na ocasião, a Federação Catarinense de Futebol, então presidida por Delfim de Pádua 
Peixoto Filho, transferiu a responsabilidade de montar a equipe à Liga Josefense de Futebol, de São José, presidida por Orivaldo Leal, que havia se tornado uma referência no futebol feminino por organizar campeonatos que reuniam equipes de todo o Estado, não apenas do município. Conforme o Diário Catarinense (1994), após alguns meses de trabalho, a Seleção disputou, em janeiro de 1994, o campeonato brasileiro de seleções, sob o comando do técnico Balduíno (João Carlos da Silva, ex-atleta de Avaí e Figueirense, professor de Educação Física na UDESC), tendo como equipe base atletas oriundas da equipe da Scorpions.

Outro destaque da década de 1990 foi a região Oeste catarinense, que em 1997 contava com 32 times em atividade, participando de competições estaduais e nacionais, com destaque para a equipe da Associação Chapecoense de Futebol, organizada em 1993, então considerada a "seleção do oeste". O time era treinado por Paulo César Pompermayer e reunia mulheres atletas de diversos municípios, como Chapecó, Tunápolis, Modelo, Nova Itaberaba, Novo Horizonte, além de cidades sul-rio-grandenses próximas, como Nonoai, Alpestre e Entre Rios. Embora atrelada ao maior time profissional da região, o time feminino não tinha patrocinadores e para reunir as atletas para um simples treinamento era uma grande dificuldade. Havia quem necessitasse se deslocar até $200 \mathrm{~km}$ para chegar a Chapecó. As passagens de ônibus eram pagas com doações, realização de jantares e promoções para a arrecadação de fundos. A situação melhorou um pouco a partir de 1997, quando o clube conseguiu providenciar alojamento para vinte e quatro atletas, com o auxílio da prefeitura municipal de Chapecó (DIÁRIO CATARINENSE, 1997, p.62).

Em seus primeiros quatro anos de existência, a Chapecoense realizou cerca de 160 jogos, perdendo apenas dois, sendo um deles para a Seleção Gaúcha. As atletas mantinham profissões diversas fora do futebol. Muitas delas eram agricultoras, que aspiravam chegar até a Seleção Brasileira, repetindo os passos de Marlisa Wahlbrink, a Maravilha, goleira da Seleção Brasileira participante do Mundial de 1999, das Olimpíadas de 2000 e 2004 . Apesar de ser nascida em Constantina, no Rio Grande do Sul, Wahlbrink ganhou tal apelido por ter sido criada no município catarinense de Maravilha, $80 \mathrm{~km}$ de distância de Chapecó, onde trabalhou na roça ao lado de oito irmãos, até decidir sair de casa para estudar em Porto Alegre, onde iniciou a carreira de atleta ao passar numa peneira no Cruzeiro, em 1994:

\footnotetext{
Como meus pais não tinham condições de dar brinquedos para todos os filhos nos períodos da Páscoa, Natal, eles sempre davam uma bola e todo mundo adorava jogar futebol. Desde pequena, desde que eu me lembro, jogava futebol em casa. Quando a gente mudava de uma residência para a outra, a primeira coisa que a gente arrumava era um campinho de futebol para poder jogar, que era o nosso divertimento. Então fui crescendo. Todos da família, as mulheres, eu tenho uma irmã, também jogava bem, eu sou a mais nova das moças. (...) $\mathrm{Na}$ escola, enquanto eu estudava, sempre jogava futebol, era a única menina que ficava no meio dos meninos. Jogava futebol ao invés de jogar vôlei, porque diferenciava, os meninos jogavam futsal e as meninas jogavam vôlei. Mas, eu sempre estava junto com os meninos, então, comecei a me destacar. Mas, mesmo assim a gente não tinha uma perspectiva, nem imaginava jogar futebol em nível nacional (WAHLBRINK, 2014, p.1-3).
}

A história de cada time feminino surgido no período pós-proibição poderia render belos ensaios de micro-história. Por exemplo, em Florianópolis, na Praia do Santinho, o time Estrela do Mar foi criado por Marta Hendler Mesquita, em 1996, quando ela tinha 41 anos (Foto 10). Nascida no interior de Torres, no Rio Grande do Sul, Marta gostava de jogar futebol desde criança com os irmãos, mas abandonou a prática na adolescência devido ao 
preconceito que sofria. Segundo Mesquita (2020), quando era aluna da Escola Técnica, ela participava de jogos organizados por sua professora de Educação Física no campo do Grêmio Esportivo Torrense, mas a professora foi coagida e ameaçada de demissão caso continuasse a estimular as garotas a jogarem futebol. Em 1996, quando residia em Florianópolis, ela sentiu que os tempos haviam mudado, juntou a filha mais velha, duas noras, mais algumas amigas e criou uma equipe para participar de amistosos e de pequenos torneios de verão disputados na praia.

A trajetória da Estrela do Mar é uma síntese das condições dos times femininos nesse período inicial pós-proibição, em que mulheres entravam em campo, sobretudo, graças a iniciativas de indivíduos e de grupos que se voltaram contra as limitações e sanções sofridas por essa prática esportiva. $\mathrm{O}$ time de Marta enfrentou grandes dificuldades até para conseguir um espaço para jogar e treinar. Somente após muita negociação com os dirigentes da associação do bairro, conseguiu a autorização para usar o campo local. Ela gostava de jogar na linha, mas virou a goleira da equipe, inspirada em Meg (Margarete Maria Pioresan), arqueira da Seleção Brasileira, na época, ainda em atividade aos quarenta anos.

Quem se destacava no Estrela do Mar era a zagueira Quelen Hendler Mesquita, filha da fundadora. Em 1997, aos 15 anos de idade, ela sonhava em defender a Seleção Brasileira. Em depoimento ao jornalista Luiz Cláudio Freitas, do Diário Catarinense (1997), Quelen apontou o maior obstáculo para a concretização de seu sonho: "Eu e minhas amigas estamos atrás de uma escolinha de futebol para meninas na Capital, mas simplesmente não existe por aqui. Que estímulo vamos ter?” (DIÁRIO CATARINENSE, 1997v, p.61).

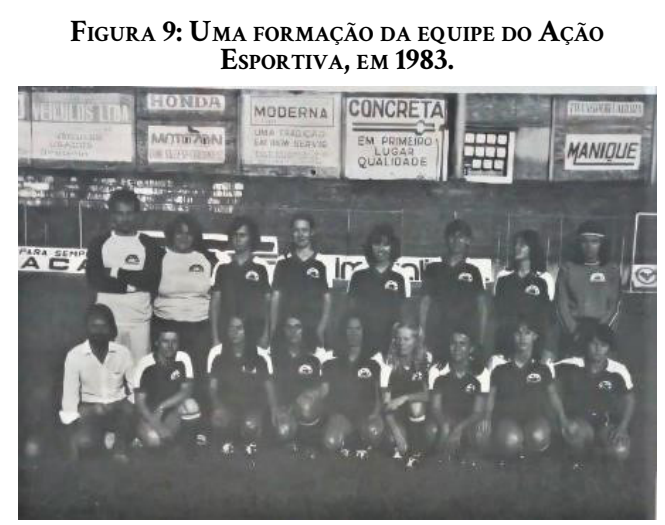

Fonte: Acervo de Adalberto Jorge Klüser
Figura 10: Marta Mesquita (a 4a em PÉ, da ESQUERDA PARA A DIREITA) E AS JOGADORAS DA Estrela Do MAR, EM 1997.v

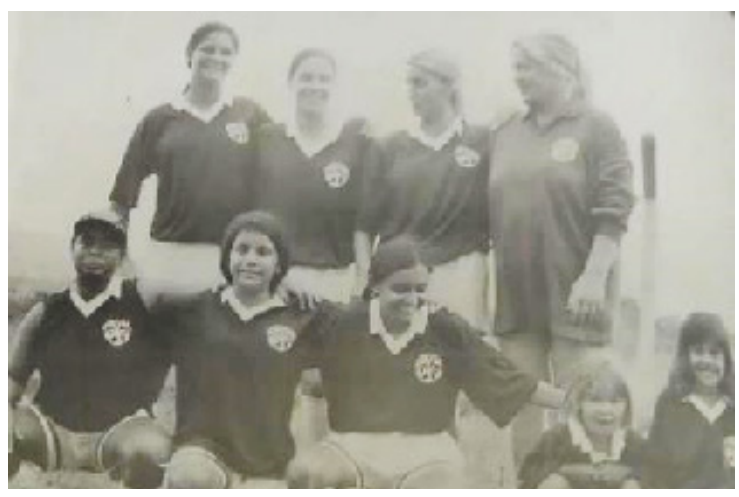

Fonte: Acervo de Adalberto Jorge Klüser.

Muitas mulheres daquele tempo devem ter se questionado da mesma maneira que Quelen, diante das dificuldades para se desenvolver como atleta e atingir um nível de profissionalismo que só seria possível, em SC, no século XXI, com o desenvolvimento de equipes como a Sociedade Esportiva Kindermann, clube em que diversas atletas com passagens pela Seleção Brasileira atuaram. Recuperar essas histórias individuais e coletivas, criar narrativas, organizar dados, explorar as representações, as subjetividades, as estratégias de opressão e de resistência que permeiam a história do futebol de mulheres no Brasil é uma forma de dar visibilidade a uma prática esportiva que por décadas ficou subjugada a tantas formas de silenciamento. 


\section{CONSIDERAÇõES FINAIS}

Apesar de suas limitações, este artigo apresentou subsídios para a realização de um variado leque de investigações que possam envolver a história das mulheres nos esportes, difundindo o conhecimento, compilando informações dispersas e organizando uma narrativa sobre a qual poderão ser elaborados trabalhos comparativos e críticos, nos mais variados campos do saber. Ao contrário do que a lacuna historiográfica possa inadvertidamente indicar, Santa Catarina possui uma longa e significativa história das mulheres no futebol, repleta de experiências impactadas pelos discursos sobre um esporte considerado "impróprio" para o corpo feminino.

De acordo com Moreira \& Prado (2019), futebol aparece como uma prática social generificada e generificante, a sofrer com interferências diretas dos dispositivos de gênero e sexualidade existentes no país. Numa sociedade em que as relações sociais foram "fundadas sobre as diferenças percebidas entre os sexos" (SCOTT, 1995, p.14), houve um investimento para assegurar que o futebol se tornasse um microcosmo predominantemente masculino de forma arbitrária e hierárquica. Tal investimento, embora tenha marginalizado as práticas esportivas femininas e retardado o seu desenvolvimento pleno, não foi bem sucedido totalmente, haja vista as práticas de resistência que possibilitaram a permanência feminina como player expressivo desse universo da bola.

Conforme Goellner (2006), por sua trajetória, não é exagero dizer que o futebol feminino é um ato de rebeldia, uma afronta às diversas relações de poder, que nunca pensaram o futebol como espaço das mulheres. Essa luta diz respeito a todos que enxergam no futebol uma possibilidade de transformação social e aos que desejam que sua popularidade no país esteja de mãos dadas com a sua diversidade, na busca por uma sociedade mais democrática e igualitária. 


\section{REFERÊNCIAS BIBLIOGRÁFICAS}

ASSOCIAÇÃO ESPORTIVA SCORPIONS. Sobre nós. Disponível em: https:// futebolfemininoscorpions.webnode.com.br/sobre-nos. Acesso em: 10 ago. 2020.

BOMBASSARO, Ticiane. \& VAZ, Alexandre F. Sobre a formação de professores para a disciplina Educação Física em Santa Catarina (1937-1945): ciência, controle e ludicidade na educação dos corpos. Educar, Curitiba, n. 33, p. 111-128, 2009.

BONFIM, Aira Fernandes. Football Feminino entre festas esportivas, circos e campos suburbanos: uma história social do futebol praticado por mulheres da introdução à proibição (1915-1941). Dissertação de Mestrado (História, Política e Bens Culturais). Fundação Getúlio Vargas: Rio de Janeiro, 2019.

BRASIL. Decreto-Lei № 3199, de 14 de abril de 1941. In: Diário Oficial da União. Poder Executivo, Brasília, DF, 18 abr. 1941, p. 7652.

BRASIL. Lei no 3.071, de $1^{\circ}$ de janeiro de 1916. Código Civil dos Estados Unidos do Brasil. Diário Oficial da União, Poder Legislativo, Brasília, DF, 5 jan. 1916. Seção 1, p.133.

BURKE, Peter. A escola dos Annales (1929 - 1989): a revolução francesa da historiografia. São Paulo, Editora da UNESP, 2010.

BUTLER, Judith. Problemas de Gênero: feminismo e subversão da identidade. Rio de Janeiro: Civilização Brasileira, 2003.

CHIZZOTTI, Antônio. A pesquisa qualitativa em ciências humanas e sociais: evolução e desafios. In: Revista Portuguesa de Educação, Braga, ano/vol. 16, n. 2. p. 221-236, 2003.

FIGOLS, Victor de Leonardo. O lugar do futebol nos simpósios da associação nacional de história (Anpuh): um balanço de 1961 a 2017. In: Revista Hydra. V. 3, n 5. dezembro de 2018.

FRANZINI, Fábio. Futebol é "coisa para macho"? Pequeno esboço para uma história das mulheres no país do futebol. In: Revista Brasileira de História, 25(50), 315-328. 2005.

FREITAS, A. L.; BORBA, B. L. de et al. O futebol no jornal das moças: as aproximações e os distanciamentos das mulheres. In: Corpoconsciência. Cuiabá-MT, vol. 23, n. 02, p. 63-74, maio/ ago., 2019.

GOELLNER, Silvana Vilodre; KESSLER, Cláudia Samuel. A sub-representação do futebol praticado por mulheres no Brasil: ressaltar o protagonismo para visibilizar a modalidade. In: Revista USP, v. 117, n. 1, p. 31-38, abr. 2018.

GOELLNER, Silvana Vilodre. Mulheres e futebol no Brasil: entre incentivos e interdições elas fazem história. In: Pensar a prática, v. 8, n. 1, p. 85-100, 2006.

GUEDES, C.M. Mulheres à cesta: o basquetebol feminino no Brasil (1892-1971). São Paulo: Miss Lily, 2009.

KLÜSER, Adalberto Jorge. Era Uma Vez no Oeste. A trajetória profissional do Palmitos. São José: Despertando Talentos, 2019.

LEAL, Daniel. O sucesso por trás dos números: por que o futebol de mulheres não para de bater recordes de audiência? In: Ludopédio, São Paulo, v. 137, n. 60, 2020.

MESQUITA, Marta Hendler. Entrevista. Entrevista concedida ao autor. Florianópolis, 01 set. 2020. 
MOREIRA, M. de F. S., PRADO, V. M. do, \& CAVALEIRO, M. C. Quando o futebol é de mulheres: suspeitas, regulações e transgressões no campo dos gêneros e sexualidades. In: Ensino Em Re-Vista, 26 (2), 524-546, 2019.

SARTORI, Carina. Na alvorada de um sport: o remo na ilha de Santa Catarina. Dissertação (Mestrado em História). Universidade Federal de Santa Catarina: Florianópolis, 2013.

SCOTT, Joan. Gênero, uma categoria útil para a análise histórica. In: Revista Educação e Realidade, Porto Alegre, v. 20, n. 2, p. 71-99, jul./dez. 1995.

SILVA, Giovana Capucim. Futebol feminino: proibido para quem? uma análise de duas reportagens sobre o futebol praticado por mulheres no período anterior a sua regulamentação. In: Anais Fazendo Gênero 10. Florianópolis, 2013.

SILVA, Giovana Capucim. Narrativas sobre o futebol feminino na imprensa paulista: entre a proibição e a regulamentação (1965-1983). Dissertação (Mestrado em História). USP, São Paulo, 2015.

SOUZA, Bruno Jeuken. Salathiel Campos: esporte e política (1926-1938). Dissertação (Mestrado em História Social) - Faculdade de Filosofia, Letras e Ciências Humanas, Universidade de São Paulo, 2018.

SOUZA, Larissa Medeiros de; MAUX, Ana Andréa Barbosa \& REBOUÇAS, Melina Séfora Souza. Impedimento? Possibilidades de relação entre a mulher e o futebol. In:Revista da Abordagem Gestáltica, 25 (3), p. 282-293, 2019.

VELLOSO FILHO, Nilo. Entrevista. Entrevista concedida ao autor. Florianópolis, 19.ago.2020.

WAHLBRINK, Marlisa. Depoimento de Marlisa Wahlbrink [Maravilha]. Projeto

Garimpando Memórias. CEME-ESEF-UFRGS: Porto Alegre, 2014. 